\title{
In vitro and in vivo antimicrobial activity of Ulva lactuca Linn. (Green algae) associated endophytic bacterial Strains
}

\author{
Prasanna Habbu ${ }^{1 *}$, Vijayanand Warad ${ }^{2}$, Rajesh Shastri ${ }^{1}$, Chetan Savant ${ }^{3}$, Smita Madagundi ${ }^{1}$, Prajact Kekare $^{4}$ \\ ${ }^{1}$ Postgraduate Department of Pharmacognosy \& Phytochemistry, SET's College of Pharmacy, Dharwad-580 002, Karnataka, India. \\ ${ }^{2}$ Centre for Research and Development, PRIST University, Thanjavur-613 403, Tamilnadu, India. \\ ${ }^{3}$ Postgraduate Department of Pharmacology, SET's College of Pharmacy, Dharwad-580 002, Karnataka, India. \\ ${ }^{4}$ Department Pharmaceutical Chemistry, Maratha Mandal's College of Pharmacy, Belgaum-590 016, Karnataka, India.
}

\begin{tabular}{l} 
ARTICLE INFO \\
\hline Article history: \\
Received on: $18 / 04 / 2016$ \\
Revised on: 09/06/2016 \\
Accepted on: $28 / 08 / 2016$ \\
Available online: $29 / 10 / 2016$ \\
\hline Key words: \\
Endophytic bacteria, Ulva \\
lactuca, antimicrobial, \\
antitubercular, HPTLC.
\end{tabular}

\begin{abstract}
The development of resistance by pathogenic microorganisms to synthetic antibiotics encouraged researchers to find novel drugs for the treatment of infectious diseases. This opened new avenues to investigate the antimicrobial efficacy of active extracts/constituents from plant endophytes. In the present study, we have isolated endophytic bacteria (ULB-I, II and III) from green algae Ulva lactuca Linn. and the same bacteria were used for fermentation and extraction. Chloroform and ethyl acetate fractions of ULB-I, II and III were prepared and screened for in-vitro antimicrobial activities and also against Kleibesella pnumoniae infected mice in-vivo. In-vitro anti-microbial activities of ULB-I, II and III were performed against pathogenic bacteria, fungi and Mycobacterium tuberculosis $H_{37} R V$ strain. From the phylogenetic analysis, the isolated endophytic organisms were identified as Bacillus subtilis JCM strain (ULB-I) and Enterobacter cloacae NBRC strain (ULB-II and III). ULB-I was found to be active against Staphylococcus aureus $(1.6 \mu \mathrm{g} / \mathrm{ml})$ and Enterococcus feacalis $(0.2 \mu \mathrm{g} / \mathrm{ml})$. The MIC against Staphylococcus aureus and Kleibesella pnumoniae was found to be $0.4 \mu \mathrm{g} / \mathrm{ml}$ for ULB-II. A significant anti-fungal activity was observed against Aspergillus flavus $(0.2-3.2 \mu \mathrm{g} / \mathrm{ml})$ and Aspergillus niger $(0.2-0.4 \mu \mathrm{g} / \mathrm{ml})$. Further, Chloroform fraction of ULB-II and ethyl acetate fraction of ULB-III have shown significant anti-tubercular activity against the tested organism with MIC of $6.25 \mu \mathrm{g} / \mathrm{ml}$. This was supported by in-vivo antimicrobial activity against $K$. pneumoniae infection in mice and least hemolytic activity against erythrocytes was observed. HPTLC analysis of above fractions further confirmed the presence of polyvalent secondary metabolites.
\end{abstract}

\section{INTRODUCTION}

Resistance to many antimicrobial agents by the microorganisms has become a worldwide problem in the treatment of several infectious diseases. Multidrug resistant organism causes several infections and threatens the human health. Tuberculosis (TB) is a major infectious disease prevalent in developing and developed countries. It is estimated that one out of 3 persons is infected with TB, especially in sub-Saharan Africa and Asia. The prevalence of $\mathrm{TB}$ in India accounts for 30\%, whereas china constitutes $40 \%$ (George et al., 2007). In spite of various

\footnotetext{
* Corresponding Author

Prasanna Habbu, Postgraduate Department of Pharmacognosy \& Phytochemistry, SET's College of Pharmacy, Dharwad-580 002,

Karnataka, India.Email: prasherbs @ yahoo.com
}

treatment regimens for $\mathrm{TB}$, still it remains a major problem in many areas of the world because of emergence of multidrug resistant (MDR) and extensively drug resistant (XDR) strains. Thus, there is an urgent need to identify effective and affordable alternative antimicrobial agents. The formulation and development of novel antimicrobial drug from a natural origin is of greater importance in biomedical research. In continuing effort by the researchers in marine natural products, many antibacterial/ antimicrobial agents have been identified (Marwa et al., 2003). In the last three decades, research on natural products from marine plants and animals is in the focus. The marine environment is known as a rich source of chemical structures with numerous beneficial health effects. Diverse arrays of natural products are obtained from marine invertebrates such as algae, sponges, tunicates, bryozoans as well as from bacteria and cyanobacteria. 
Among marine organisms, marine algae and sponge species have been identified as an under-exploited plant resource, although they have long been recognized as valuable sources of structurally diverse bioactive compounds. Recently, microalgae metabolites are attracting to enormous attention, and the topics have been discussed by a number of authors. The microalgal phyla have been recognized to provide compounds with chemical and pharmacological novelty and diversity (Shimizu et al., 1996). Algae are a rich source of therapeutically active components and possess wide range of activities such as antimicrobial (Zbakh et al., 2012), antiviral (Bouhlal et al., 2011), anti-allergic (Na HJ et al., 2005), anti-coagulant (Dayong et al., 2008), anticancer (Kim et al., 2011) and antioxidant activities (Devi et al., 2011). Macroalgae has self-protecting nature against other organisms present in the environment by producing several secondary metabolites such as alkaloids, polyketides, cyclic peptides, phlobatannins, diterpenoids, sterols, quinines and lipids with many biological activities (Al-Saif et al., 2014).

Marine endophytes are of great interest as novel and rich sources of biologically active products. They live in close association with soft-bodied marine plants, which lack obvious structural defense mechanisms, and thus rely on chemical defense by production of bioactive secondary metabolites, either by themselves or by associated microflora, to survive in their extreme habitat (Jensen et al., 1994). Throughout the years, extensive screening programs were developed worldwide and great efforts have been devoted aiming at the isolation at new metabolites from marine microorganisms. Helicascolide-C from endophytic fungus Daldiniae schscholzii of red algae (Kustiariyah et al., 2012), Cyclic tetrapeptides isolated from Pseudomonas sp. and Pseudoalteromonas sp. of seaweed Digineasp (Wimolpun et al., 2008). 6-Oxo-de-methyllasiodiplodin, (E)-9-Etheno-lasiodiplodin, Lasiodiplodin, de-o-Methyllasiodiplodin and 5-Hydroxy-de-Omethylasiodiplodin from endophytic fungus ZZF36 associated with brown alga (Sargassum sp.), Cristatumin-E, from a fungus Eurotium herbariorum HT-2 associated with algae Enteromorpha prolifera (Ye Li et al., 2013) and Penicisteroid- A from an endophytic fungus Penicillium chrysogenum QEN-24S associated with red algae of the genus Laurencia (Shu-Shan et al., 2011) are some important antimicrobial secondary metabolites obtained from algal- derived endophytic microbes.

Ulva lactuca is a member of green macroalgae known as chlorophyceae. These macroalgae have been reported to possess antioxidant (Zubia et al., 2007) and antimicrobial activities (Soltaniet al., 2010). Fatty acids and sterols were isolated from macroalgae by GC/MS (Santos et al., 2015). The epibiotic bacterial strain UL1 of marine algae exhibited broad spectrum inhibitory activity against 7 pathogens (Chellaram et al., 2013), cytoprotective activity of antioxidant components from algal and vegetable source were reported (Botta et al., 2014). Three monounsaturated fatty acid (MUFA) derivatives as active components were isolated from green alga which includes a new keto-type $\mathrm{C}_{18}$ fatty acid, the corresponding shorter chain $\mathrm{C}_{16}$ acid, an amide derivative $C_{18}$ acid (Wang et al., 2013). Considering the above facts, the present work aims to isolate bacterial endophytes from Ulva lactuca Linn. for their possible action against pathogenic microbes following in-vitro and in-vivo methods.

\section{MATERIALS AND METHODS}

\section{Collection and authentication of green algae}

Algal samples of Ulva lactuca Linn. were collected in rocky shores of Someshwar beach, located at Mangalore, Dakshina Kannada district, Karnataka, India in October 2013. The collected algal samples were stored in flasks with sterile sea water and maintained in low temperature. It was authenticated as Ulva lactuca by Dr. Bindu Sulochana, Senior Scientist, Central Marine Fisheries Research Institute, Mangalore, Karnataka, India. The Voucher specimen of the algae (Voucher Nos. 11-13/2013) was deposited at Department of Pharmacognosy and Phytochemistry, SET's College of Pharmacy, Dharwad, Karnataka, India.

\section{Isolation of endophytes from Ulva lactuca Linn.}

After collection, the samples were rinsed with sterile sea water to remove associated debris. The cleaned material was then surface dried by pressing it briefly between sheets of paper toweling and air dried in the shade at $30^{\circ} \mathrm{C}$ for 24 hours. Epiphytes were removed of the algae by washing the algal samples for ten minutes with $30 \%$ ethanol (Hellio et al., 2000). Then, the algal samples were surface sterilized by $4 \%$ sodium hypochlorite for 5 min, $70 \%$ ethanol for $1 \mathrm{~min}$ and sterile distilled water for $1 \mathrm{~min} 2-$ 3 times. The surface sterilized pieces were transferred to an alcohol sterilized mortar and macerated separately in to suspension using distilled water and serial dilutions were made. The diluted aliquots were transferred on sterile nutrient agar plate. After incubation at $37{ }^{\circ} \mathrm{C}$ for $15-18$ hours, predominant isolates of bacteria were picked up and purified. The selected isolates were observed for their morphological characteristics (Geraldo et al., 2005, Subhash et al., 2013).

\section{Fermentation and preparation of crude fractions}

Pure bacterial isolates were grown on nutrient agar plates at $37^{\circ} \mathrm{C}$ for 24 hours depending on growth rate. Five bacterial isolates were identified and designated as ULB-I, II, III, IV and V respectively and used for fermentation and extraction. Purified isolates of each bacteria were inoculated and fermented separately in Erlenmeyer flask containing nutrient broth for 7-14 days at $37^{\circ} \mathrm{C}$ under stationary condition. Each bacterial broth was filtered through four layer of cheese cloth and homogenized with blades at $4000 \mathrm{rpm}$ to crush (bacteria lysis) the bacterial cell from broth. Chloroform and ethyl acetate extraction of the filtrate was carried out in triplicate. The organic phase was separated to dryness under reduced pressure using rotary evaporator (Superfit Rotavap, PBU6) and weighed. In this study, ULB I, II and III were taken for invitro and in-vivo antimicrobial studies and further for characterization of endophytes by sequential analysis. The yield of each extract ranged from $60-80 \mathrm{mg} / \mathrm{L}$ of fermented medium. Each fraction was mixed with the same solvent and subjected to preliminary phytochemical investigations \& antimicrobial assays. 


\section{Preliminary phytochemical investigations}

Chloroform and ethyl acetate extracts of ULB I, II and III were subjected to qualitative analysis to identify the presence of group of active components following established procedures.

\section{Study design}

Test Organisms: Enterococcus fecalis (ATCC-35550), Kleibesella pnumoniae (ATCC-29665), Staphylococcus aureus (ATCC-12598), Escherichia coli (ATCC-25922), Candida albicans (ATCC-2091), Aspergillus flavus sp. (ATCC-204304), Aspergillus niger (ATCC- 9029).

\section{In-vitro antimicrobial activity}

Nine dilutions of each test samples were made with brain heart infusion broth (BHI) for MIC. 10mg of compound was dissolved in $1 \mathrm{ml}$ of DMSO i.e solvent. Then 10 test tubes were arranged serially. In first test tube $300 \mu 1$ of BHI was added and from $2^{\text {nd }}$ to $10^{\text {th }}$ tube $200 \mu \mathrm{l}$ of BHI was added. After that $100 \mu \mathrm{l}$ of drug was added to $1^{\text {st }}$ tube (master dilution). Then $200 \mu \mathrm{l}$ of master dilution was transferred to $2^{\text {nd }}$ tube and likewise we did till $10^{\text {th }}$ tube. $200 \mu \mathrm{l}$ was discarded from $10^{\text {th }}$ tube. Then $200 \mu \mathrm{l}$ of organism was added from $1^{\text {st }}$ tube to last tube and incubated the tubes in incubator for 24 hours at $37^{\circ} \mathrm{C}$. After $24^{\text {th }}$ hrs tubes were observed for turbidity (Schwalve et al., 2007). Ciprofloxacin and Fluconazole were used as standard drugs for antibacterial and antifungal activity.

\section{In-vitro antituberculosis activity}

The anti-mycobacterial activity of test fractions was assessed against Mycobacterium tuberculosis $\left(3 \times 10^{5} \quad \mathrm{CFU} / \mathrm{ml}\right.$ concentration of bacteria) $H_{37} R V$ using microplate Alamar Blue assay (MABA).This methodology is non-toxic, uses a thermally stable reagent and shows good correlation with proportional and BACTEC radiometric method. Briefly, $200 \mu 1$ of sterile deionzed water was added to all outer perimeter wells of sterile 96 wells plate to minimized evaporation of medium in the test wells during incubation. The 96 wells plate received $100 \mu 1$ of the Middlebrook $7 \mathrm{H} 9$ broth and serial dilution of compounds was made directly on plate. The final drug concentrations tested were 100 to $0.2 \mu \mathrm{g} / \mathrm{ml}$. Plates were covered and sealed with parafilm and incubated at $37^{\circ} \mathrm{C}$ for five days. After this time, $25 \mu \mathrm{l}$ of freshly prepared 1:1 mixture of Almar Blue reagent and 10\% Tween-80 was added to the plate and incubated for 24 hours. A blue color in the well was interpreted as no bacterial growth, and pink color was scored as growth. The MIC was defined as lowest drug concentration which prevented the colour change from blue to pink (Maria et al., 2007). In this method Pyrazinamide, Streptomycin and Ciprofloxacin were used as standard drugs.

\section{Determination of cellular toxicity to human erythrocytes}

Chloroform and ethyl acetate endophytic fractions of ULB-I, ULB-II, ULB-III were further investigated for cellular toxicity of RBC's. Blood was obtained from blood bank of Karnataka medical college, Hospital and research centre, Hubli,
India. Human erythrocytes were isolated from the blood by removing buffy coat and suspended in PBS (10 mM phosphate, $150 \mathrm{mM}$ sodium chloride, $\mathrm{PH}$ 7.4) which were dispensed in sugar tubes which are used for blood collection, the interior wall of which is coated with BCA (blood coagulation accelerator $\left(10^{10}\right.$ cells $/ 500 \mu \mathrm{l} /$ tube). The serial dilutions of endophytic fractions were made and mixed with erythrocytes keeping final volume of $1 \mathrm{ml}$. The cells were incubated for $1 \mathrm{hr}$ at $37^{\circ} \mathrm{C}$ and finally centrifuged at $1500 \mathrm{~g}$ for $10 \mathrm{~min}$. Lysis of the cells was observed by determining absorbance at $600 \mathrm{~nm}$ using colorimeter. The respective dilution of test compounds (without erythrocytes) was used as blank for determination of absorbance. The erythrocytes were completely lysed by treatment with $1 \%$ Triton-X100 and absorbance of the released haemoglobin was taken as $100 \%$ lysis (He et al., 1994).

\section{In-vivo antimicrobial activity}

Swiss mice of either sex (20-22 g) were used in the study. All the animals were given a standard pellet diet and water ad libitum. Animals were checked daily for their mortality and morbidity prior to commencement of the study and only healthy animals were included in the experiment (Healthy animals are selected as per CPCSEA guidelines). Techniques used for the bleeding, injection as well as sacrifice of animal were approved by the Animals Ethics Committee as per CPCSEA guidelines. Each animal was challenged by $200 \mu \mathrm{l}$ of Klebseilla pneumoniae overnight culture of $5 \times 10^{5}$ was obtained as per McFarland scale in normal saline $(0.9 \%)$ through intravenous route. The drug treatment was started 24 hours post infection. Suspensions of chloroform and ethyl acetate fractions of ULB-II was prepared in Tween 80 and administered orally at a dose of $100 \mathrm{mg} / \mathrm{kg}$ body weight, Control group animals were given normal saline. Test compounds were administered for 7 days and necessary precautions were taken to administer specified dose of the drug to the experimental animals. In this study Chloramphenicol was used as standard drug (Figure 1)

\section{PCR sequential analysis of 16s rRNA gene of ULB-1 and II}

The genomic DNA was isolated from the given organism using genomic DNA extraction kit (Bhat Biotech Ltd. Bangalore, India). Amplification of the 16s rRNA gene was performed using the primers. Forward primer: 5'AGAGTTTGATCCTGGCTCAG-3', Reverse Primer: 5'ACGGCTACCTTGTTACGACTT-3'PCR was performed as follows in a total volume of $50 \mu \mathrm{L}$ in a $0.2 \mathrm{ml}$ thin walled PCR tube. The amplification was carried out in a Master cycler ${ }^{\circledR}$ Thermocycler (DNA-AMP Bhat Biotech) using the following program. Initial Denaturation was carried out at $94^{\circ} \mathrm{C}$ for 2 minutes followed by 40 cycles of Denaturation at $94{ }^{\circ} \mathrm{C}$ for a minute, annealing at $55{ }^{\circ} \mathrm{C}$ for a minute and extension at $72{ }^{\circ} \mathrm{C}$ for minute. Final extension was carried out at $72{ }^{\circ} \mathrm{C}$ for 10 minutes. The $\sim 1500$ bp PCR product was purified to remove unincorporated dNTPS and Primers before sequencing using PCR purification kit (GENEASY PCR PRODUCT PURIFICATION, KIT, Bangalore, India). Both strands of the rDNA region amplified by PCR were 
sequenced by automated DNA sequence $-3037 x$ l DNA analyzer from Applied Biosystems using BigDye ${ }^{\circledR}$ Terminator v3.1 cycle sequencing Kit (Applied Biosystems). Cluster analysis was performed by an un-weighted paired-group method for the arithmetic average (UPGMA). Neighbor-joining method (NJM) was used to estimate the phylogram based on the idea of parsimony and the tree is usually close to the true phylogenetic tree (Saitou and Nei 1978; Rohlf, 1993). Sequence data were aligned and dendrograms were generated using sequence analysis software version 5.2 from applied biosystems. The sequences obtained for plus and minus strands were aligned using appropriate software before performing bioinformatics. Sequences were compared to the non-redundant NCBI database using BLASTN, with the default settings used to find sequences closest to each other. The expected value and E- values were noted for the most similar sequences. Ten similar neighbors were aligned using CLUSTAL W2. The multiple-alignment file thus obtained was then used to create a phylogram using the MEGA5 software.

\section{High Performance Thin Layer Chromatography of ULB-I and II}

$10 \mathrm{mg}$ of the Chloroform and ethyl acetate fractions of ULB-I and II were dissolved in $1.0 \mathrm{ml}$ of chloroform and ethyl acetate respectively. 8 and $12 \mu$ l of chloroform fractions of ULB-I and II,10 and $15 \mu \mathrm{l}$ of ethyl acetate fractions of ULB-I and II were applied on a pre-coated silica gel F254 on aluminum plates to a band width of $7 \mathrm{~mm}$ using Linomat 5 TLC applicator. The plate was developed in Hexane: Ether: Acetic acid (6.0: 4.0: 0.1) and Hexane: Ether: Acetic acid (5.0: 5.0: 1.0). The developed plates were visualized in UV $254 \mathrm{~nm}$ and then derivatised with vanillin sulphuric acid reagent and scanned under UV 254nm and $620 \mathrm{~nm}$. $\mathrm{R}_{\mathrm{f}}$ values, colour of the spots and densitometric scan were recorded (Harborne et al., 1998, Wagner et al., 1996).

\section{RESULTS}

The yield of chloroform and ethyl acetate fractions were found to be $1.24 \mathrm{~g} / \mathrm{l}$ and $0.3 \mathrm{~g} / \mathrm{l}$ for ULB-I, $0.77 \mathrm{~g} / \mathrm{l}$ and $0.16 \mathrm{~g} / \mathrm{l}$ for ULB-II and $0.65 \mathrm{~g} / \mathrm{l}$ and $0.35 \mathrm{~g} / \mathrm{l}$ for ULB-III respectively. Preliminary phytochemical investigations of ULB I, II and III fractions revealed the presence of alkaloids, steroids and triterpenoids and flavanoids as important constituents (Table 1). The results of antimicrobial activities (MIC) of the compounds against the selected two Gram- positive, two Gram-negative bacteria are shown in Table 2 . The activity of ciprofloxacin and norfloxacin are used as standard. All the compounds showed moderate to significant microbial inhibition. Chloroform fractions of ULB I,II and III have shown MIC of $0.2,3.12,3.12 \mu \mathrm{g} / \mathrm{ml}$ against Enterococcus faecalis respectively, Whereas MIC of ethyl acetate fractions was more than $100 \mu \mathrm{g} / \mathrm{ml}$. The MIC of chloroform and ethyl acetate fractions of ULB- II against Klebesella pneumoniae was found to be $0.4 \mu \mathrm{g} / \mathrm{ml}$ respectively. The lowest MIC against Staphyllococcus aureus among the fraction tested was $0.4 \mu \mathrm{g} / \mathrm{ml}$ for ULB-II followed by $1.6 \mu \mathrm{g} / \mathrm{ml}$ and $3.2 \mu \mathrm{g} / \mathrm{ml}$ for chloroform fraction of ULB I and III respectively. Chloroform and ethyl acetate fraction of ULB-II has shown MIC of $50 \mu \mathrm{g} / \mathrm{ml}$ against Eschereichia coli. A significant antifungal activity was observed against Aspergillus Flavus (MIC range 0.2-3.2 $\mu \mathrm{g} / \mathrm{ml}$ ) and Aspergillus niger (MIC range 0.2-6.25 $\mu \mathrm{g} / \mathrm{ml})$, where as MIC was more than $100 \mu \mathrm{g} / \mathrm{ml}$ against Candida albicans for ULB I, II and III fractions.

Table 1: Qualitative phytochemical analysis of endophytic fractions of Ulva lactuaca.

\begin{tabular}{cccccccc}
\hline $\begin{array}{c}\text { S. } \\
\text { No. }\end{array}$ & $\begin{array}{c}\text { Name of the } \\
\text { phytoconstituent }\end{array}$ & \multicolumn{2}{c}{ ULB-I } & & ULB-II & & \multicolumn{2}{c}{ ULB-III } \\
\hline & & C & E & C & E & C & E \\
01 & Alkaloids & + & - & - & - & + & - \\
02 & Steroids & + & - & + & + & + & + \\
03 & Tannins & - & - & - & - & - & - \\
04 & Saponins & - & - & - & - & - & - \\
05 & Triterpenoids & - & + & + & - & - & - \\
06 & Flavonoids & - & + & - & + & - & + \\
\hline
\end{tabular}

C- Chloroform fraction; E: Ethyl acetate fraction

+ indicates the presence of the component

- indicates the complete absence of the component

Table 2: Efficacy of different endophytic fractions of Ulva lactuca against pathogenic bacteria and fungi (Values are mean of two replications).

\begin{tabular}{|c|c|c|c|c|c|c|c|}
\hline \multirow{2}{*}{$\begin{array}{l}\text { Sl } \\
\text { No }\end{array}$} & \multirow[t]{2}{*}{ Test organism } & \multicolumn{2}{|c|}{$\begin{array}{c}\text { ULB-I } \\
(\mathrm{MIC}-\mu \mathrm{g} / \mathrm{ml})\end{array}$} & \multicolumn{2}{|c|}{$\begin{array}{c}\text { ULB-II } \\
(\text { MIC- } \mu \mathrm{g} / \mathrm{ml})\end{array}$} & \multicolumn{2}{|c|}{$\begin{array}{c}\text { ULB-III } \\
(\text { MIC- } \mu \mathrm{g} / \mathrm{ml})\end{array}$} \\
\hline & & $\mathbf{C}$ & $\mathbf{E}$ & $\mathbf{C}$ & $\mathbf{E}$ & $\mathbf{C}$ & $\mathbf{E}$ \\
\hline 1 & $\begin{array}{l}\text { Enterococcus } \\
\text { fecalis }\end{array}$ & 0.2 & 100 & 3.12 & 100 & 3.12 & 100 \\
\hline 2 & $\begin{array}{l}\text { Kleibesella } \\
\text { pnumoniae }\end{array}$ & $>100$ & 100 & 0.4 & 0.4 & $>100$ & $\begin{array}{l}>10 \\
0\end{array}$ \\
\hline 3 & $\begin{array}{l}\text { Staphylococcus } \\
\text { aureus }\end{array}$ & 1.6 & 100 & 0.4 & 0.4 & 3.2 & 100 \\
\hline 4 & $\begin{array}{l}\text { Escherichia } \\
\text { coli }\end{array}$ & $>100$ & 50 & 50 & 50 & 50 & 100 \\
\hline 5 & $\begin{array}{l}\text { Candida } \\
\text { albicans }\end{array}$ & $>100$ & 100 & 100 & $>100$ & $>100$ & 100 \\
\hline 6 & $\begin{array}{l}\text { Aspergillus } \\
\text { Flavus }\end{array}$ & 0.2 & 0.4 & 3.2 & 0.8 & 3.2 & 1.6 \\
\hline 7 & $\begin{array}{l}\text { Aspergillus } \\
\text { niger }\end{array}$ & 0.4 & 6.25 & 0.2 & 0.2 & 0.4 & 0.2 \\
\hline
\end{tabular}

C- Chloroform fraction; E- Ethyl acetate fraction.

In anti-tubercular assay against Mycobacterium tuberculosis $H 37 R V$ strain, chloroform fraction of ULB-II and ethyl acetate fraction of ULB III has shown MIC of 6.25 MIC $\mu \mathrm{g} / \mathrm{ml}$ respectively. However, for ethyl acetate fractions of ULB I and II, chloroform fraction of ULB-III.the MIC was found to be $12.5 \mu \mathrm{g} / \mathrm{ml}$. The results are shown in Table 3 .

Table 3: Antitubercular activity of different endophytic fractions of Ulva lactuca against Mycobacterium tuberculosis $\mathrm{H}_{37}$ sensitive strain.

\begin{tabular}{ccc}
\hline Endophytic fractions & \multicolumn{1}{c}{ MIC $(\mu \mathrm{g} / \mathrm{ml})$} \\
\hline & Chl. & EA \\
\hline ULB-I & 25 & 12.5 \\
ULB-II & 6.25 & 12.5 \\
ULB-III & 12.5 & 6.25 \\
\hline
\end{tabular}

C - Chloroform fraction; E - Ethyl acetate fraction 
Table 4: Efficacy of ULB-II endophytic fractions of Ulva lactuca on K. pneumoniae infection in mice.

\begin{tabular}{|c|c|c|c|c|c|c|c|c|c|c|c|}
\hline \multirow[t]{2}{*}{ Test compounds } & \multicolumn{11}{|c|}{ No of days/ Percentage of protection } \\
\hline & $\mathbf{0}$ & 1 & 2 & 3 & 4 & 5 & 6 & 7 & 8 & 9 & 10 \\
\hline Control & 100 & 100 & 100 & 90 & 70 & 20 & NS & NS & NS & NS & NS \\
\hline ULB-II (C) & 100 & 100 & 100 & 100 & 100 & 100 & 80 & 60 & 40 & 40 & 40 \\
\hline ULB-II (E) & 100 & 100 & 100 & 100 & 100 & 100 & 100 & 80 & 60 & 60 & 60 \\
\hline
\end{tabular}

Swiss albino mice $(\mathrm{n}=30)$ were challenged with $5 \times 10^{5} \mathrm{cfu}$ of $K$. pneumoniae. The animals were treated with ULB-II endophytic fractions $(100 \mathrm{mg} / \mathrm{kg}$ body weight) daily for 7 days. C - Chloroform fraction; E - Ethyl acetate fraction.

Results of haemolysis assay suggested that ethyl acetate fractions of ULB I, II, III caused least erythrocytic haemolysis as compared to chloramphenicol (Figure 1). In-vivo studies demonstrated the survival data on day $10^{\text {th }}$ of post treatment of ULB-II endophytic fractions. The results showed that about $40 \%$ of animals treated with chloroform fraction and $60 \%$ of animals treated with ethyl acetate fraction of ULB-II were survived respectively. All the control animals were died within 6 days. The results are shown in Table 4.

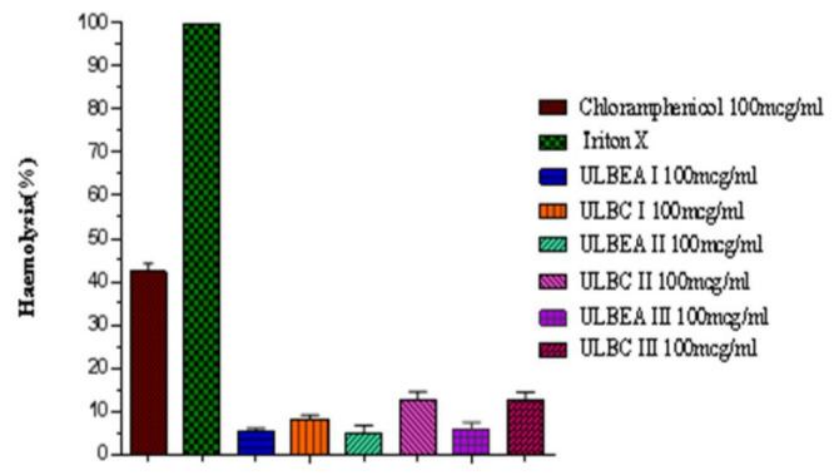

Fig. 1: Effect of chloroform and ethyl acetate fractions of ULB-I and II on cellular toxicity of RBCs. (The values are mean \pm S.E.M of three experiments).

The sequence of the 16s RNA gene from ULB-I and II and that of matching sequences from 10 nucleotide sequences were aligned using the maximum likelihood method based on the Tamura-Nei model (Figure 2).

ULB-I

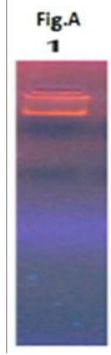

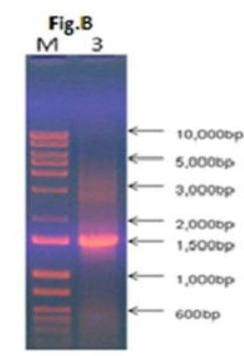

Fig. 2: Genomic DNA isolation and PCR amplification of the 16srRNA gene of ULB-I and II Figure 1. A) Genomic DNA extracted from ULB-I and II, separated on $0.8 \%$ Agarose gel electrophoresis and visualized with propidium Iodide. B) PCR product $1.5 \mathrm{~kb}$ in size separated on $0.8 \%$ Agarose gel electrophoresis and visualized with propidium Iodide. M- $1 \mathrm{~kb}$ DNA ladder (Fermentas), Lane 3 ULB- I and II sample.

The tree with the highest log likelihood (-2031.3921) is shown. Initial tree(s) for the heuristic search were obtained automatically as follows. When the number of common sites was $<100$ or less than one fourth of the total number of sites, the maximum parsimony method was used; otherwise BIONJ method with MCL distance matrix was used. The analysis involved 10 nucleotide sequences. Codon positions included were $1 \mathrm{st}+2 \mathrm{nd}+3 \mathrm{rd}+$ Noncoding.

All positions containing gaps and missing data were eliminated. There were a total of 1416 positions in the final dataset. Evolutionary analyses were conducted in MEGA5.The sequences of ULB-I and II were compared with existing sequences in the NCBI database using the Blast $\mathrm{N}$ programme (Figure 3).

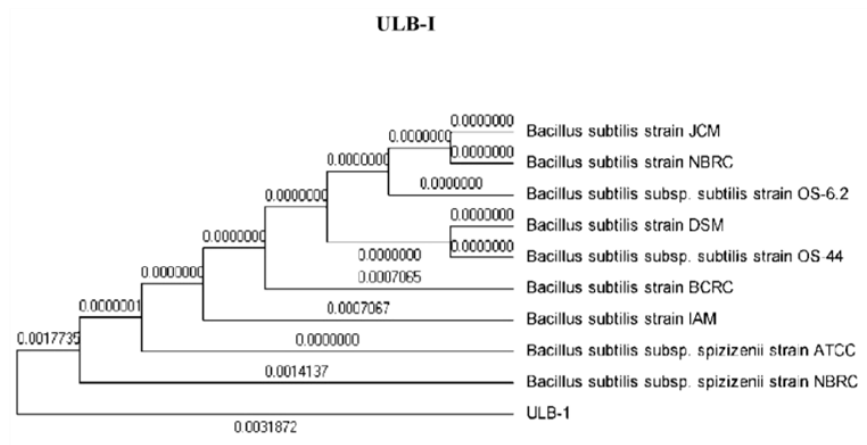

ULB-II

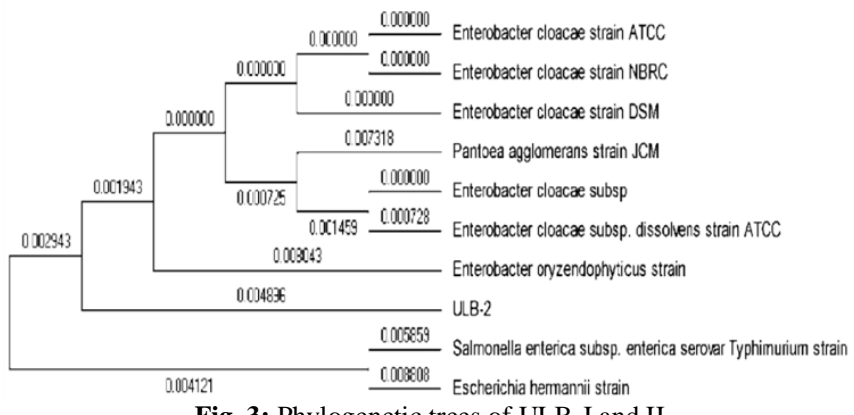

Fig. 3: Phylogenetic trees of ULB-I and II.

A high score and low expect value indicates greatest homology. Based on these results ULB-I and II were identified as Bacillus subtilis JCM strain and Enterobacter cloacae strain NBRC respectively. The microscopic view of the identified organisms is shown in Figure 4 and 5. 
HPTLC fingerprint of ULB-I-C scanned at wavelength $254 \mathrm{~nm}$ showed the presence of nine polyvalent secondary metabolites. The corresponding ascending order of $\mathrm{R}_{\mathrm{f}}$ values start from 0.02 to 0.92 in which highest concentration of the metabolite was found to be $44.07 \%$ and its corresponding $\mathrm{R}_{\mathrm{f}}$ value was found to be 0.28 .

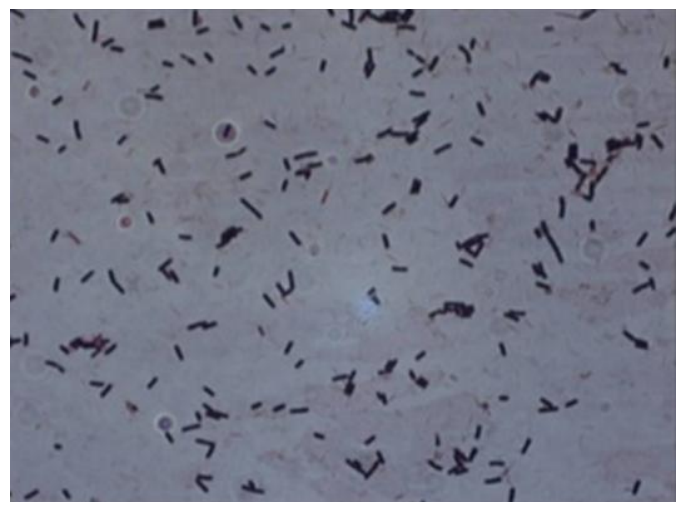

Fig. 4: Microscopic view of endophytic bacteria Bacillus subtilis JCM strain.

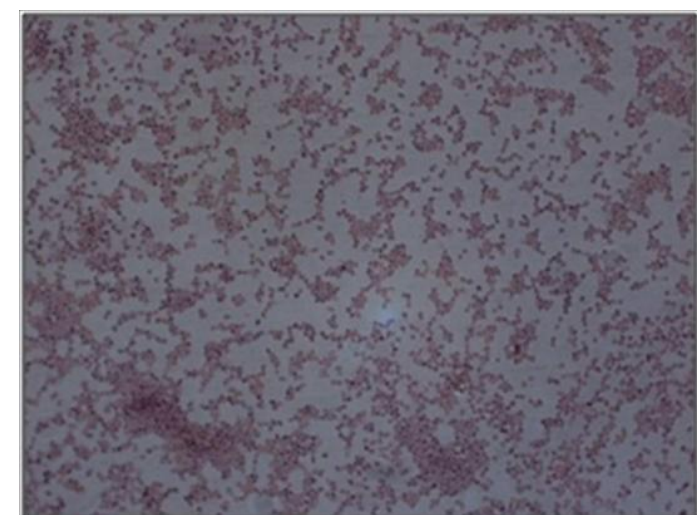

Fig. 5: Microscopic view of endophytic bacteria Enterobacter cloacae strain NBRC strain.

In case of ULB-II-C six polyvalent constituents were observed and the range of $R_{\mathrm{f}}$ values was from 0.02 to 0.93 . The maximum concentration of $49.46 \%$ was observed for the component with $\mathrm{R}_{\mathrm{f}}$ value 0.02 .

Scanning of ULB-I-C at $620 \mathrm{~nm}$ showed six spots with the $\mathrm{R}_{\mathrm{f}}$ value range from 0.02 to 0.91 with highest concentration of $35.71 \%$ corresponding to $\mathrm{R}_{\mathrm{f}}$ value of 0.02 . Six spots were also observed for ULB-II-C with the $\mathrm{R}_{\mathrm{f}}$ value range 0.03 to 0.89 . Maximum concentration was observed for $R_{f}$ value of 0.63 having $38.25 \%$. (Figure 6 and 8).

HPTLC analysis of ULB-I-E and ULB-II-E at wavelength $254 \mathrm{~nm}$ showed the presence of five and nine polyvalent constituents with $\mathrm{R}_{\mathrm{f}}$ values ranging from 0.01 to 0.91 and 0.01 to 0.98 respectively. In both the fractions spot corresponding to $R_{f}$ value 0.01 was found to be present in higher concentration of about $65.19 \% 45.34 \%$ for ULB-I-E and ULB-II-E respectively. However, at $620 \mathrm{~nm}$ ULB-II-E has shown a maximum concentration corresponding to the spot with $\mathrm{R}_{\mathrm{f}}$ value 0.02 (Figure 6 and 7).
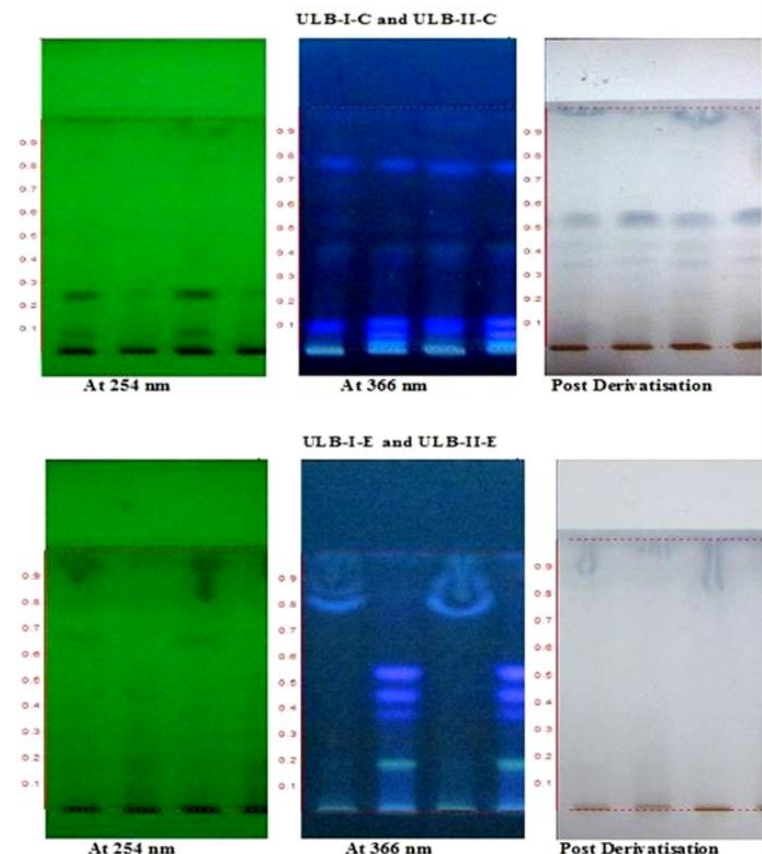

At $366 \mathrm{~nm}$

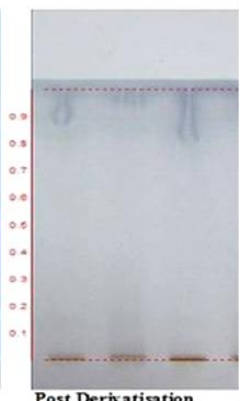

Fig. 6: HPTLC photo documentation of ULB-I-C and ULB-II-C ${ }^{1}$; ULB-I-E and ULB-II-E at $254 \mathrm{~nm}, 366 \mathrm{~nm}$ and post derivatisation. Solvent systems ${ }^{1}$ Hexane: diethyl ether: Acetic acid (6: 4: 0.1); ${ }^{2}$ Hexane: diethyl ether: Acetic acid (5.0: 5.0: 1.0).
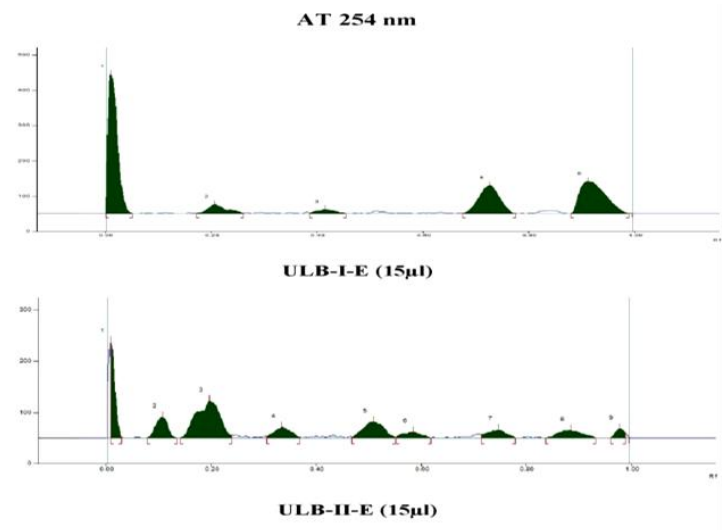

$A T 620 \mathrm{~nm}$
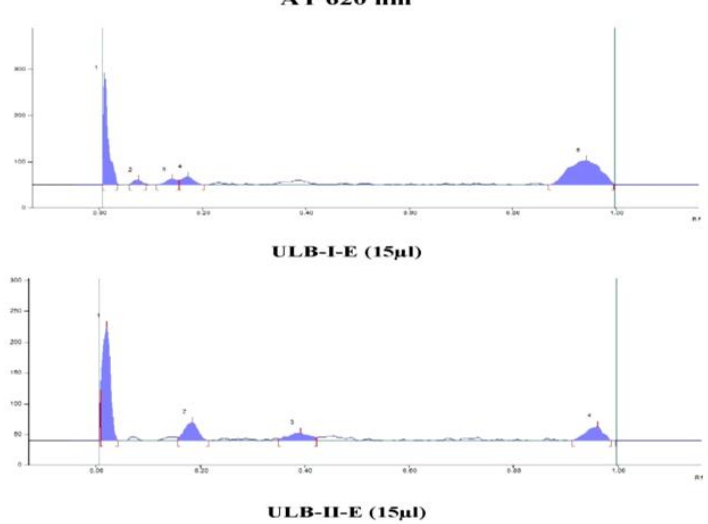

Fig. 7: Chromatograms of ethyl acetate fractions of ULB-I and ULB-II at 254 $\mathrm{nm}$ and $620 \mathrm{~nm}$ 

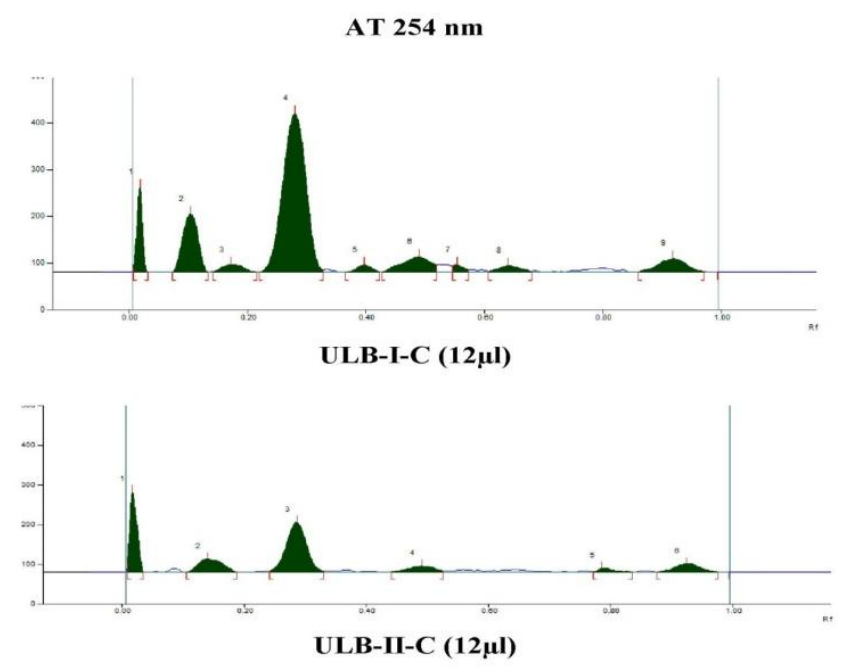

AT $620 \mathrm{~nm}$
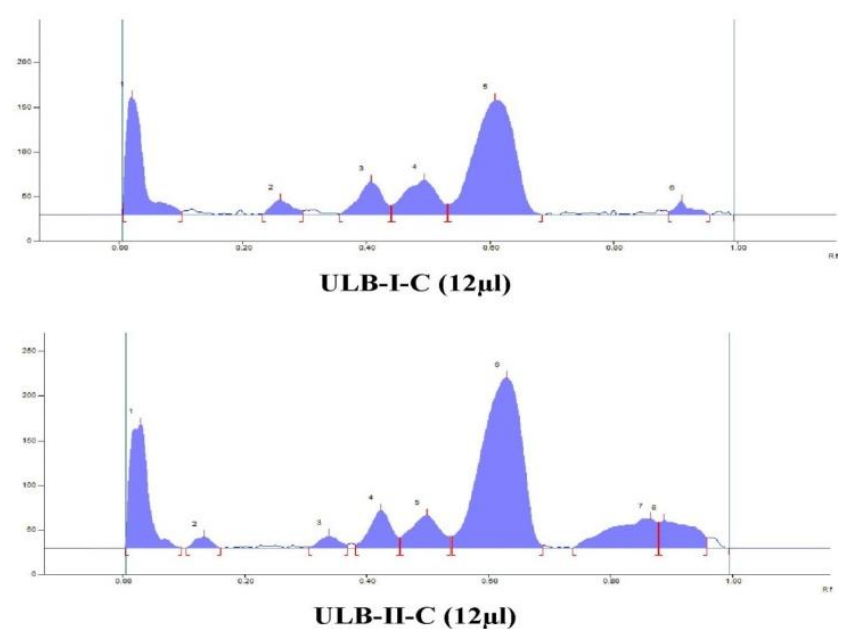

Fig. 8: Chromatograms of chloroform fractions of ULB-I and ULB-II at 254 $\mathrm{nm}$ and $620 \mathrm{~nm}$

\section{DISCUSSION}

Drug resistance in bacteria has become a global concern and the search for new antibacterial or anti-tubercular agents is urgent and need of the hour. Endophytes provide a rich source of secondary metabolites from medicinal plants and marine source, and an increasing number of novel compounds are being isolated from endophytic algae, fungi, bacteria, actinomycetes etc (Hanqiao et al., 2012). Exploitation of novel classes of antimicrobial/antitubercular metabolites have noticeably increased over recent years. A considerable amount of research was carried out with respect to diversity, ecological role, secondary metabolites and bioactivity of the endophytic organisms from various medicinal plants/marine sources (Vaz et al., 2009).

In the present investigation, we have isolated and identified three endophytic bacteria (ULB-I, II \& III) from ulva lactuva (green algae). Through phylogenetic /sequential analysis the organisms were identified as Bacillus subtilis JCM strain (ULB-I) and Enterobacter cloacae NBRC strain (ULB-II \&III).
However, this is the first report on in-vitro and in-vivo antimicrobial activity of chloroform and ethyl acetate fractions of these organisms. Preliminary phytochemical analysis of ULB I, II and III non-polar fractions revealed the presence of alkaloids, steroids, triterpenoids and flavonoids as important constituents.

Bacillus subtilis is one of the common endophytic organisms associated with medicinal plants and possessing broad spectrum activity against plant pathogen. Many reports suggested the antifungal, antibiotic, cytotoxic, antidiabetic and antihyperlipidemic activities of endophytic bacillus Sps. Novel secondary metabolites like lipopeptides, Oxylipins, Limnazine, beta-1,3-1, 4-glucanase are reported from bacillus Sps. (Gond et al., 2015, Trapp et al., 2015, Chen et al., 2013, Asolkar et al., 2002, Zouari et al., 2015, Jin et al., 2011, Liu et al., 2009). Enterobacter cloacae. is a rod-shaped, Gram-negative bacteria from the Enterobacteriaceae family. The size of this bacteria ranges from 0.3-0.6 x 0.8-2.0 $\mu \mathrm{m}$. An Enterobacter cloaca lives in the mesophilic environment with its optimal temperature at $37^{\circ} \mathrm{C}$ and uses its peritrichous flagella for movement. This organism is oxidase negative but catalase positive and is facultative anaerobic. In other words, this organism can make ATP by aerobic respiration when oxygen is present but can switch to fermentation in the absence of oxygen. Earlier reports suggested that Pyocyanin and exopolysacharide were isolated from this organism (Scott et al., 2006, Wing-YL et al., 2012, Iyer et al., 2005). Therefore, to the best of our knowledge this is the first investigation to report the antibacterial activities of Ulva lactuca associated endophytic organisms.

Antimicrobial activities of chloroform and ethyl acetate were performed against pathogenic bacteria, fungi and Mycobacterium tuberculosis H37Rv strain. Chloroform and ethyl acetate fraction of ULB I, II and III exhibited MIC at $3.12 \mu \mathrm{g} / \mathrm{ml}$ against Enterococcus faecalis where as MIC of chloroform and ethyl acetate fraction of ULB I, II and III against Klebesella pneumoniae showed moderate activity. The lowest MIC against Staphyllococcus aureus among the fraction tested was $0.4 \mu \mathrm{g} / \mathrm{ml}$ for ULB-II followed by ULBI and III respectively. A significant antifungal activity was observed against Aspergillus Flavus and Aspergillus niger, where as MIC was moderate against Candida albicans. This action may be attributed to inhibition of synthesis of fungal sterol by ULB-I, II and III fractions (Mahmoud et al., 1999).

TB is one of the major infectious diseases affecting mankind in developed and developing countries (Janinet al., 2007). Mycobacterium tuberculosis is one of the leading opportunistic infection in patients with the acquired immune deficiency syndrome and also due to the spread of multidrug-resistant strains (Ibrahim et al., 2007). Natural chemistry is one of the major fields of research. Natural products or their semi-synthetic derivatives can lead to development of novel anti-mycobacterial drugs which play an important role in the chemotherapy of tuberculosis in future (Pavanet al., 2007). From the earlier report we came to know that crude extract of Streptomyces sp. Y3111 isolated from the stems of Heracleu msouliei, showed good anti-BCG activity 
with an MIC value of $12.5 \mu \mathrm{g} / \mathrm{mL}$. Bioassay-guided isolation yielded four new pluramycin-type compounds named heraclemycins $\mathrm{A}, \mathrm{B}, \mathrm{C}$ and $\mathrm{D}$ along with two known compounds, $\beta$-indomycinone and saptomycin A (Miaomiao et al., 2013). Antituberculosis activity of Phomopsis stipata associated with the leaves of S. Camporum was also reported (Karina et al., 2012). To our best knowledge this is the report in-vitro anti-tubercular activity of $B$. subtilis and enterobacter cloacae strains isolated from ulva lactuva. Chloroform fraction of ULB-II and ethyl acetate fraction of ULB III have shown good anti-TB activity against the tested organism with MIC of $6.25 \mu \mathrm{g} / \mathrm{ml}$ respectively. However, for ethyl acetate fractions of ULB I and II, chloroform fraction of ULB-III, the MIC was found to be $12.5 \mu \mathrm{g} / \mathrm{ml}$ respectively. This was further supported by in-vivo antimicrobial activity against $K$. pneumoniae infection in mice and least haemolytic activity against erythrocytes was observed.

Thus, we can conclude that the antimicrobial activity of chloroform and ethyl acetate fractions of ULB-I,ULB-II and ULBIII may be attributed due to the presence of alkaloids, steroids, triterpenoids and flavonoids as major secondary metabolites. HPTLC analysis revealed the chemical diversity of chloroform and ethyl acetate fractions of ULB-I and II. Further investigations are warranted to isolate and identify marker compound(s) responsible for antimicrobial activity.

\section{ACKNOWLEDGEMENT}

We are thankful to Dr. Bindu Sulochana, Senior scientist, Central Marine Fisheries Research Institute (CMFRI) for identification of the algae. We thank Principal SET's College of Pharmacy and President, Soniya Education Trust for encouragement and support to carry out the research work.

Financial support and sponsorship: The authors are thankful to All India Council for Technical Education (AICTE) (Ref: 20/AICTE/RIFD/RPS (Policy-III) 62/2012-13) for funding under research promotion scheme (RPS).

Conflict of Interests: There are no conflicts of interest.

\section{REFERENCES}

George AG, Kanyawim KK, Pattama PK, et al. In search of cyclooxygenase inhibitors, anti-mycobacterium tuberculosis and antimalarial drugs from Thai flora and microbes. Pharmacol Ther, 2007; 115: 307-351.

Marwa D, Mark TH. Marine natural products and their potential applications as anti-infective agents. Lancet Infect Dis, 2003; 3: 338-347.

Shimizu Y. Microalgal metabolites: a new perspective. Ann Rev Microbiol, 1996; 50: 431-465.

Zbakh H, Chiheb H, Bouziane H, Motilva SV. Antibacterial activity of benthic marine algae extracts from the Mediterranean coast of morocco. J Microbiol Biotechnol Food Sci, 2012; 1: 219-228.

Bouhlal R, Haslin C, Chermann JC, et al. Anti-viral activities of sulphated polysachrides isolated from Sphaclococcus Coronopifolius and Boergeseniellathuyoides. Mar Drugs, 2011; 9: 1187-1209.

Na HJ, Moon PD, Lee HJ, et al. Regulatory effect of atopic allergic reaction by carpopeltisaffinis. J Ethnopharmacol, 2005; 101: 4348.
Dayong S, Jing L, Shuju G, Lijun H. Antithrombotic effect of bromophenol, the alga-derived thrombin inhibitor. J Biotechnol, 2008; 136: $577-588$

Kim SK, Thomas NV, Li X. Anticancer compounds from marine macroalgae and their application as medicinal foods. Adv Food Nut Res, 2011; 64:213-224.

Devi GK, Manivannan K, Thirumaran G, Rajathi FA, Anantharaman P. In vitro antioxidant activities of selected seaweeds from southeast coast of India. Asian pacific J Trop Med, 2011; 4: 205-211.

Al-Saif SS, Abdel-Raouf N, El-Wazanani HA, Aref IA. Antibacterial substances from marine algae isolated from Jeddah coast of Red Sea. Saudi Arabia. Saudi. J Biol Sci, 2014; 21: 57-64.

Jensen PR, Fenical W. Strategies for the discovery of secondary metabolites from marine bacteria: ecological perspectives. Ann Rev Microbiol, 1994; 48: 559-584.

Kustiariyah T, Gottfried JP, Andrea P et al. Helicascolide C, A new lactone from an Indonesian marine algicolous strain of Daldinia eschscholzii (Xylariaceae, Ascomycota). Phytochem Lett, 2012; 5:83-86.

Wimolpun R, Eric R, Siwu, et al. Cyclic tetrapeptides from marine bacteria associated with the seaweed Diginea sp. and the sponge. Halisarcaectofibrosa. J Tetrahedron, 2008; 64(14): 3147-3152.

Ye Li, Kun-Lai S, Yi Wang, et al. A cytotoxic pyrrolidinoindoline diketopiperazine dimer from the algal fungus Eurotium Herbariorum HT-2. Chin Chem Lett, 2013; 24 (12): 1049-1052.

Shu-Shan G, Xiao-Ming L, Chun-Shun L, et al. Penicisteroids $\mathrm{A}$ and $\mathrm{B}$, antifungal and cytotoxic polyoxygenated steroids from the marine alga-derived endophytic fungus Penicillium chrysogenum QEN24S. Bio org Med Chem Lett, 2011;21: 2894-2897.

Zubia M, Robledo D, Freile PY. Antioxidant activities in tropical marine macroalgae from the Yucatan peninsula, Mexico. J Appl Phycol, 2007; 19: 449-458.

Soltani S, Ali E, Khoshrooei R, Rahmani Z. Antibacterial and antihemolytic activities of Enteromorphis intestinalis in Caspian sea coast. Iran J Med Plants Res, 2010; 6: 530-533.

Santos SA, Vilela C, Freire CS, Abreu MH, Rocha SM, Silvestre AJ. Chlorophyta and Rhodophyta macroalgae: a source of health promoting phytochemicals. Food Chem, 2015; 183(15): 122-128.

Chellaram C, Raja P, John AA, Krithika S. Antagonistic effect of epiphytic bacteria from marine algae, southeastern India. Pak J Biol Sci, 2013; 16(9): 431-4.

Botta A, Martinez V, Mitjans M, Balboa E, Conde E, Vinardell MP. Erythrocytes and cell line-based assays to evaluate the cytoprotective activity of antioxidant components obtained from natural sources. Toxicol, 2014; 28(1): 120-4.

Wang R, Paul VJ, Luesch H. Seaweed extracts and unsaturated fatty acid constituents from the green alga Ulva lactuca as activators of the cytoprotective Nrf2-ARE pathway. Free Radic Biol Med, 2013; 57:141153.

Hellio C, Bourgougnon N, Le- Gal Y. Phenoloxidase (E.C. 1.14.18.1) from Mytilus edulis byssus gland: purification, partial characterization and application for screening products with potential antifouling activities. Biofouling, 2000;16: 235-244.

Geraldo HS, Helder LT, Henrique CT, et al. New bioactive metabolites produced by Phomopsis cassiae, an endophytic fungus in Cassia spectabilis. J Braz Chem Soc, 2005; 16(6): 1463-1466.

Subhash JB, Reavicharater N, Chye YL. Screening of endophytic bacteria isolated from leaves of Sambung Nyawa (Gynura Procumbens (Lour.) Merr.) for cytokinein type compounds, Bioinformation, 2013; 5(5):191-197.

Schwalve M, Goodwin S. 2007. Antimicrobial susceptibility testing protocols. Crc Press,

Maria CS, Lourenco Marcus V, D Souza N, et al. Evaluation of anti-Tubercular activity of nicotinic and isoniazid analogues. ARKIVOC (xv), 2007; 181-191.

He X, Mocek U, Floss HG, et al. An antifungal compound from Solanum nigrescens. J Ethanopharmacol, 1994; 43(3): 173-175.

Harborne JB.1998. Phytochemical methods. Edn 3, London: Chapman and Hall,. Wagner H, Baldt S. 1996. Plant drug analysis; Edn 2, Berlin: Springer, 
Hanqiao L, Yongmei X, Juan C, Zhang D, Shunxing G, Wang C. Antimicrobial activities of endophytic fungi isolated from Ophiopogon japonicas. BMC Complement Altern Med, 2012; 12: 238-242.

Vaz AB, Mota RC, Bomfim MR, et al. Antimicrobial activity of endophytic fungi associated with Orchidaceae in Brazil. Can J Microbiol, 2009; 55:1381-1391.

Gond SK, Bergen MS, Torres MS, White JF. Endophytic Bacillus spp. produces antifungal lipopeptides and induce host defence gene expression in maize. Microbiol Res, 2015;172:79-87.

Trapp MA, Kai M, Mithofer A, Rodrigues FE. Antibiotic oxylipins from Alternanthera brasiliana and its endophytic bacteria. Phytochemistry, 2015; 110: 72-82.

Chen X, Li J, Sun Q, Tong Y, Xu J. Isolation, purification and characterization of antifungal protein from rice endophytic bacterim Bacillus subtilis G87. Wei Sheng Wu XueBao, 2013; 2: $543-546$

Asolkar RN, Kamat VP, Wagner DI, Laatsch H, Limnazine S. The first bacterial azine derivative from Bacillus sp. GW90a. J Nat Prod, 2002; 65(11): 1664-6.

Zouari R, Ben Abdallah-KR, Hamden K, et al. Assessment of the antidiabetic and antilipidemic properties of Bacillus subtilis SPB1 biosurfactant in alloxan-induced diabetic rats. Biopolymers, 2015; 10:1002-1006.

Jin Z, Zhou W, Wang Y, et al. Antibacterial effect and cytotoxicity of beta-1,3-1, 4-glucanase from endophytic Bacillus subtilis SWB8. Acta Microbiol. Sin., 2011; 51(11): 1527-37.

Liu B, Qiao H, Huang L, et al. Biological control of take-all in wheat by endophytic Bacillus subtilis E1R-j and potential mode of action. Biol Control, 2009; 49: 277-285.

Scott A, Bennie J, Howard W, Coran MH. Pyocyanin Isolated from a Marine Microbial Population: Synergistic production between two distinct bacterial species and mode of action. Chem Biol, 2006; 13: 13491359.

Wing-YL, Karl MKC, Chi FW, et al. Complete Genome Sequence of the Endophytic Enterobactercloacae subsp. cloacae Strain ENHKU01. J Bacteriol, 2012; 194:5965-5968.
Iyer A, Mody $\mathrm{K}$, Jha $\mathrm{B}$. Characterization of an exopolysaccharide produced by a marine Enterobactercloacae. Ind J Exp Biol, 2005; 3(5): 467-71.

Mahmoud A, Ghannoum P, Louis BR. Antifungal Agents: Mode of Action, Mechanisms of Resistance, and Correlation of These Mechanisms with Bacterial Resistance. Clin Microbiol Rev, 1999; 4: 5015171

Janin YL, Antituberculosis drugs: Ten years of research. Bioorg Med Chem, 2007; 15(7): 2479-513.

Ibrahim M, Andries K, Lounis N et al. Synergistic activity of R207910 combined with pyrazinamide against murine tuberculosis. Antimicrob. Agents Chemother, 2007; 51(3): 1011-1015.

Ronconi L, Sadler PJ. Using coordination chemistry to design new medicines. Coord. Chem. Rev., 2007; 251: 1633-1637.

Pavan FR, Leite CQ, Coelho RG, et al. Evaluation of antiMycobacterium tuberculosis activity of Campomanesia adamantium (Myrtaceae). Quim. Nova, 2007; 32: 1222-1226.

Miaomiao Liu, Wael M, Abdel-MB, et al. Endophytic Streptomyces sp. Y3111 from traditional Chinese medicine produced antitubercular pluramycins. Appl. Microbiol. Biotechnol, 2013; 253 (13): 5335-5336.

Karina A, De Prince, Renata Sordi, et al. Anti-Mycobacterium tuberculosis activity of fungus Phomopsis stipata. Braz J Microbiol, 2012; 43:1590.

\section{How to cite this article:}

Habbu P, Warad V, Shastri R, Savant C, Madagundi S, Kekare P. In vitro and in vivo antimicrobial activity of Ulva lactuca Linn. (Green algae) associated endophytic bacterial Strains. J App Pharm Sci, 2016; 6 (10): 138-146. 